\title{
Concentration of Particulate Matter below 10 and 2.5 Micron in air of Shiraz, Iran
}

\author{
ARMIN, MASHAYEKHAN; *MEHDI, SHAYEGH \\ Department of Environment, Yazd Branch, Islamic Azad University, Yazd, Iran. Email: \\ * Corresponding author Email: mashaykhan@gmail.com
}

\begin{abstract}
According to the United Nations Environment Programme, particulate matter is the most important air pollutant in large cities around the world, released from many sources into the air. Since one of the main causes of air pollution in Shiraz is also particulate matter, monitoring the particles is necessary to develop control programs; therefore the aim of this study was to measure the concentration of particulate matter less than 10 and 2.5 micron in air of Shiraz and compare same with EPA and National Standards. In this study, 45 stations were selected and sampling was performed in mornings and afternoons using Dust trak device. So during three sampling months (June, July and August), 90 samples for $\mathrm{PM}_{2.5}$ (45 in morningd and 45 in afternoons) and 90 samples for $\mathrm{PM}_{10}$ (45 in mornings and 45 in afternoons) and a total of 180 samples were taken. During the sampling for $\mathrm{PM}_{10}$, July with an average of $17.1 \mu \mathrm{g} / \mathrm{m}^{3}$ was the spottiest month and August with an average of $13 \mu \mathrm{g} / \mathrm{m}^{3}$ was the cleanest month. Also for $\mathrm{PM}_{2.5}$, July with an average of $11 \mu \mathrm{g} / \mathrm{m}^{3}$ was the spottiest month and August with an average of $8.67 \mu \mathrm{g} / \mathrm{m}^{3}$ was the cleanest month. Results showed that the concentration of $\mathrm{PM}_{2.5}$ and $\mathrm{PM}_{10}$ was less than standards in most cases.
\end{abstract}

\section{DOI: $\underline{\text { https://dx.doi.org/10.4314/jasem.v22i7.4 }}$}

Copyright: Copyright $\odot 2018$ Armin and Mehdi. This is an open access article distributed under the Creative Commons Attribution License (CCL), which permits unrestricted use, distribution, and reproduction in any medium, provided the original work is properly cited.

Dates: Received: 09 April 2018; Revised: 30 May: 2018; Accepted: 11 June 2018

Keywords: Air pollution, Standards, Particulate matter

Uncontrolled expansions of cities, together with the rapid economic development and consequently increased energy consumption have caused many environmental problems for inhabitants. Air pollution in cities is one of the most important of these problems, which is always a permanent and serious threat to the health of the communities as well as the environment. The effects of air pollution on human health have been of interest to researchers and public for decades. While Air pollution control programs have been used since the early decades of the twentieth century in many developed industrial countries in order to maintain human health and to prevent environmental degradation, air pollution situation in the developing countries is deteriorating (Jamshidi et al., 2005). Today, the issue of air pollution from the social, economic, political and technical point of view is the subject that has a special place in the world and one of the issues raised in this area is to prevent the increase of this pollution and find the causes and factors behind it. In addition, pollutants and particulate matter such as $\mathrm{PM}_{2.5}$ and $\mathrm{PM}_{10}$ are the main causes of air pollution (Azizifar et al., 2011). In different times, different aspects of pollution have been investigated.

On a small scale, local pollution that causes the effects of simple disturbances to dangerous and latent illnesses is under consideration and issues such as depletion of ozone layer, acid rain and Global warming are being discussed in the global context. The sources of air pollution at the beginning of the industrial revolution were mainly industries and coal consumption and in $21^{\text {st }}$ century, transportation is the reason of air pollution in cities. Fossil fuels consumption for transportation and the use of raw materials and manufactured products for industrial processes are the major causes of anthropogenic pollution (Hatami et al., 2012). According to the United Nations Environment Programme, particulate matter is the most important air pollutant in large cities around the world, released from many sources into the air. The dust that spreads from the ground into the air by wind together with dust from forest fires and volcanoes, viruses, bacteria and pollen are considered as natural sources of particulate matter, while unnatural sources include combustion of fuel, particles from various processes in industries, particles from crushing and rubbing materials, traffic and vehicles. According to World Health Organization, the mortality rate increases by 1 to $3 \%$ per an increase of $10 \mu \mathrm{g} / \mathrm{m}^{3}$ of particulate matter (Jamshidi et al., 2005). These materials as a branch of pollutants are very diverse and complex and like their concentration in air, their particle size and chemical composition are also important (Afyuni and Erfanmanesh, 2008). Scientific studies conducted over the past two decades have shown that particulate matter is important from the view point of public health. The World Health

*Corresponding author Email: mashaykhan@gmail.com 
Organization has estimated that 500,000 people per year die of exposure to airborne particulate matter in the open air. Particulate matter increases the risk of respiratory death, affects the function of the lungs, exacerbates asthma and causes other respiratory symptoms such as coughing and bronchitis, while these particles also increase the risk of other respiratory diseases. Exposure to Air pollution caused by particulate matter causes spontaneous heart reactions such as increased heart rate, reduced cardiac flexibility and increased cardiac arrhythmias. Among other effects of particulate matter are global warming, degradation of properties and effects on plants (Lily et al., 2009).

City of Shiraz, the capital city of Fars province, has a length of $40 \mathrm{~km}$ and a width between 15 to $30 \mathrm{~km}$ with an area of $1268 \mathrm{~km}^{2}$ and a rectangle shape and is geographically located in the southwest of Iran in the central part of Fars province. The geographical coordinates of Shiraz are: $29^{\circ} 36^{\prime} \mathrm{N}$ and $52^{\circ} 32^{\prime} \mathrm{E}$ with an elevation ranges between 1480-1670 $\mathrm{m}$ in different parts of the city. This city has a Mediterranean climate. The average annual temperature is $18{ }^{\circ} \mathrm{C}$ and the annual rainfall is $337.8 \mathrm{~mm}$. The total population of Shiraz in 2011 was $1,460,665$ and including the population living in the suburbs reaches 1,700, 687 . Nowadays, Shiraz is called Electronic Center of Iran. Currently, there are about 40 major active industries in the city. Manufacturing industries in Shiraz have a very small contribution to the air pollution due to the accurate control of activities of these industries. However, the main factor creating particulate matter into the air of Shiraz is related to traffic and vehicles, which its volume is increasing every day. Regarding the specific topographical and climate conditions, traveling over 500,000 vehicles in this city as one of the seven major polluted cities in Iran is the source of these particles and other pollutants. A large part of this pollution is due to the poor performance of vehicles' engine.

Since one of the main causes of air pollution in Shiraz is particulate matter, monitoring of these particles and the continuous determination of air quality in order to develop control programs is necessary; therefore the aim of this study was to measure the concentration of airborne particulate matter and to compare them with the standards.

\section{MATERIALS AND METHODS}

This study was a descriptive-cross sectional one in Shiraz during June, July and August 2015. Sampling was done in mornings and afternoons based on EPA guidelines for particulate matter. In this study, 45 stations were selected for sampling. Thus, during the sampling period, 90 samples were taken for $\mathrm{PM}_{2.5}$ (45 in mornings and 45 in afternoons) and 90 samples for $\mathrm{PM}_{10}$ (45 in mornings and 45 in afternoons) and a total of 180 samples were taken. The following statistical relationship known as the Cochran formula was used to determine the sampling points:

$\mathrm{n}=\frac{z^{2} p q}{d^{2}}$

Where $\mathrm{n}=$ sample size or number of points; $\mathrm{Z}^{2}=\mathrm{a}$ constant value that depends on the confidence interval and the error level, and is equal to $1.96 ; \mathrm{q}=\mathrm{p}=$ ratio of observations $=0.5$; and $\mathrm{d}=$ confidence level or desirable probability $=1.0$. Finally, 45 stations were selected for sampling after some modifications.

To measure the concentration of particulate matter $\left(\mathrm{PM}_{10}\right.$ and $\left.\mathrm{PM}_{2.5}\right)$, sampling device of Dust Trak model 85100 (TSI Co., Ltd., USA) was used. Using this device, the average, maximum and minimum values were calculated in $\mathrm{mg} / \mathrm{m} 3$ and after the sampling period, these values were converted to $\mu \mathrm{g} / \mathrm{m} 3$ for statistical analysis by computer. SPSS and Excel programs were used for statistical analysis of particles' concentration and drawing charts and tables.

\section{RESULTS AND DISCUSSION}

The maximum and minimum daily concentration of $\mathrm{PM}_{10}$ was observed in June equal to $49 \mu \mathrm{g} / \mathrm{m}^{3}$ and in June equal to $3 \mu \mathrm{g} / \mathrm{m}^{3}$, respectively. The maximum and minimum average of daily $\mathrm{PM}_{10}$ concentration was observed in July equal to $1.17 \mu \mathrm{g} / \mathrm{m}^{3}$ and in August equal to $13 \mu \mathrm{g} / \mathrm{m}^{3}$, respectively. The maximum and minimum daily concentration of $\mathrm{PM}_{2.5}$ was related to July equal to $31 \mu \mathrm{g} / \mathrm{m}^{3}$ and in this month equal to 1 $\mu \mathrm{g} / \mathrm{m}^{3}$, respectively. The maximum and minimum average of daily $\mathrm{PM}_{2.5}$ concentration was related to July equal to $11 \mu \mathrm{g} / \mathrm{m}^{3}$ and in August equal to $8.67 \mu \mathrm{g} / \mathrm{m}^{3}$, respectively.

According to graph 1 for June, the maximum and minimum average of $\mathrm{PM}_{10}$ concentration was 25 and $6 \mu \mathrm{g} / \mathrm{m}^{3}$, respectively and for $\mathrm{PM}_{2.5}$ concentration was 18 and $4 \mu \mathrm{g} / \mathrm{m}^{3}$, respectively. As it can be seen in graph 2 for July, the maximum and minimum average of $\mathrm{PM}_{10}$ concentration was 30 and $11 \mu \mathrm{g} / \mathrm{m}^{3}$, respectively and for $\mathrm{PM}_{2.5}$ concentration was 24 and $5 \mu \mathrm{g} / \mathrm{m}^{3}$, respectively. According to graph 3 for August, the maximum and minimum average of $\mathrm{PM}_{10}$ concentration was 19 and $6 \mu \mathrm{g} / \mathrm{m}^{3}$, respectively and for $\mathrm{PM}_{2.5}$ concentration was 16 and $5 \mu \mathrm{g} / \mathrm{m}^{3}$, respectively. The phenomenon of air pollution in urban and industrial areas is one of the most important environmental problems and threatens human health. Among these pollutants is particulate matter and the 
mortality rate increases by 1 to $3 \%$ per an increase of $10 \mu \mathrm{g} / \mathrm{m}^{3}$ of particulate matter (Hatami et al., 2012). The present study was conducted to determine the concentration and pollution of airborne particulate matter in Shiraz. To assess the status and extent of pollution, the measured concentrations can be compared with the reference and standard values, which were done in the current study. National and international standards are presented in tables 1 and 2 and then the results are mentioned:

Table 1: EPA standard for particulate matter at three time intervals

\begin{tabular}{lllll}
\hline $\begin{array}{l}\text { average } \\
\text { hour of 24- } \\
\text { concentration }\end{array}$ & $\begin{array}{l}\text { average of 24-hour } \\
\mathrm{PM}_{10} \text { concentration }\end{array}$ & time & Standards \\
\hline 65 & & 150 & 1997 & EPA \\
35 & & 150 & 2006 & \\
35 & 150 & 2012 & \\
\hline
\end{tabular}

Table 2: Clean Air (National) Standards for particulate matter at three time intervals

\begin{tabular}{llll}
\hline $\begin{array}{l}\text { average of 24-hour } \\
\mathrm{PM}_{2.5} \text { concentration }\end{array}$ & $\begin{array}{l}\text { average of 24- } \\
\text { hour } \\
\text { concentration }\end{array}$ & time & Standards \\
\hline 150 & 150 & 1388 & National \\
30 & 90 & 1389 & \\
25 & 50 & 1390 & \\
\hline
\end{tabular}

Comparison of particulate matter concentrations with EPA and national standards showed that fortunately, the concentrations measured throughout the sampling period were less than the standards. The maximum daily concentration of $\mathrm{PM}_{10}$ in June, July and August was less than the standard limit, while the maximum daily concentration of $\mathrm{PM}_{2.5}$ in June and July was greater than the national standard in 2011 and then the national standard in 2010 and 2011, respectively. One of the most important causes of air pollution in large and densely populated cities is permanent atmospheric conditions, especially temperature inversion in winter. Since the study was conducted in June, July and August, i.e. in the spring and summer, it can explain the low concentration of particles in the aforementioned period. Dust storms and haze are other factors in increasing the particulate matter, which has occurred in the west, southwest and most recently in the center of Iran in recent years. These dust storms have been occurred in springs and summers just a few years ago, but nowadays they cover eight months of the year and in addition to the southwestern regions of the country, they have become widespread in most provinces of the country and metropolitan areas such as Tehran, Isfahan and Shiraz (Arfaeinia et al., 2014). Of course, there was no dust storm at the time of the current study; therefore, it can be considered another reason of low concentration of of particles in the study period. In a study conducted by Lily et al. (2009) in the central area of Tehran in the mornings and evenings, they found that $\mathrm{PM}_{10}$ concentrations measured during the whole sampling period were lower than the standard limit (According to the 1997 standard and the new 2006 standard of United States Environmental Protection Agency). According to the 1997 standard, the average measured concentrations of $\mathrm{PM}_{2.5}$ were below the standard limits, while were more than 2006 standard. Results of Azizifar et al. (2011) also showed that the concentration of particulate matter was less than standard limit in most cases.

Table 3: Statistical description of airborne particulate matter in

\begin{tabular}{lllll}
\multicolumn{5}{c}{ Shiraz } \\
\hline August & July & June & \\
\hline 13 & 17.1 & 14.23 & average & $\mathrm{PM}_{10}$ \\
3.43 & 5.1 & 4.5 & standard deviation & \\
25 & 44 & 49 & maximum & \\
4 & 4 & 3 & minimum & \\
8.67 & 11 & 8.97 & average & $\mathrm{PM}_{2.5}$ \\
2.94 & 4.07 & 3.23 & standard deviation & \\
22 & 31 & 29 & maximum & \\
2 & 2 & 1 & minimum & \\
\hline
\end{tabular}

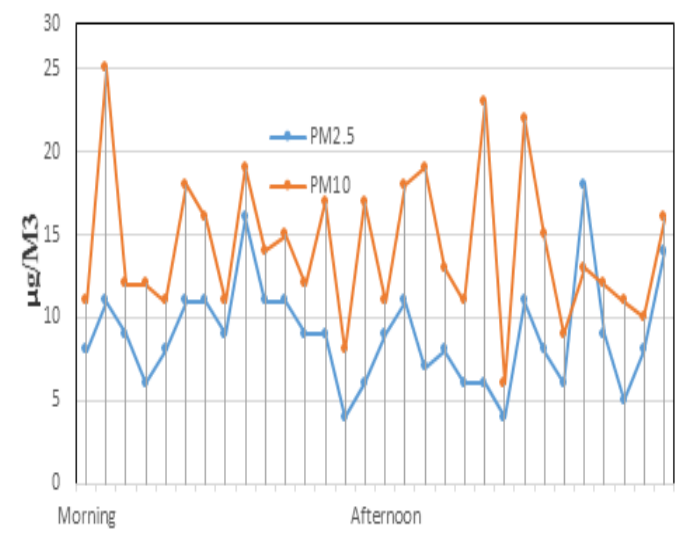

Fig 1: Average concentrations of particulate matter in June

In general, it can be said that, during the sampling period for $\mathrm{PM}_{10}$, July with an average of $1.17 \mu \mathrm{g} / \mathrm{m}^{3}$ was the spottiest month and August with an average of $13 \mu \mathrm{g} / \mathrm{m}^{3}$ was the cleanest month. For $\mathrm{PM}_{2.5}$, July with an average of $11 \mu \mathrm{g} / \mathrm{m}^{3}$ was the spottiest month and August with an average of $8.67 \mu \mathrm{g} / \mathrm{m}^{3}$ was the cleanest month. Azizifar et al. (2011) studied the concentration of particulate matter in the air of Qom during summer and autumn seasons. During the sampling period for $\mathrm{PM}_{10}$, October with an average of $117 \mu \mathrm{g} / \mathrm{m}^{3}$ was the spottiest month and September with an average of $83 \mu \mathrm{g} / \mathrm{m}^{3}$ was the cleanest month. For $\mathrm{PM}_{2.5}$, November with an average of $33 \mu \mathrm{g} / \mathrm{m}^{3}$ was the spottiest month and August, September and October with an average of $8 \mu \mathrm{g} / \mathrm{m}^{3}$ were the cleanest months. In addition, Houthuijs et al. (2001) measured the concentrations of $\mathrm{PM}_{2.5}$ and $\mathrm{PM}_{10}$ in Poland and results showed an increase in the concentration of

$\mathrm{PM}_{10}$ during the warm season from 18 to $45 \mu \mathrm{g} / \mathrm{m}^{3}$. 


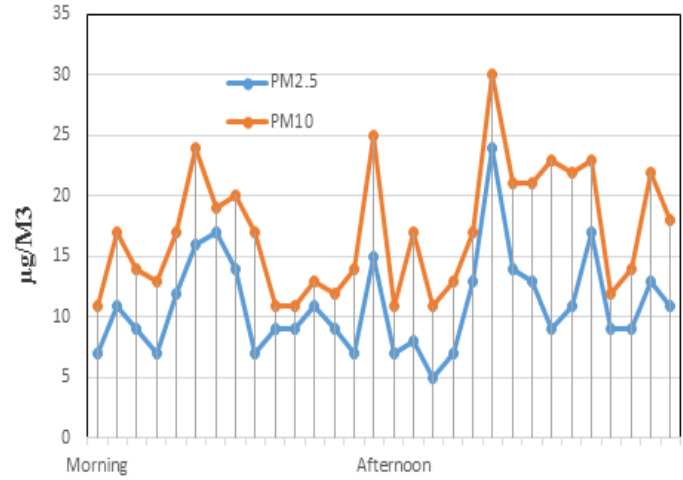

Fig 2: Average concentrations of particulate matter in July

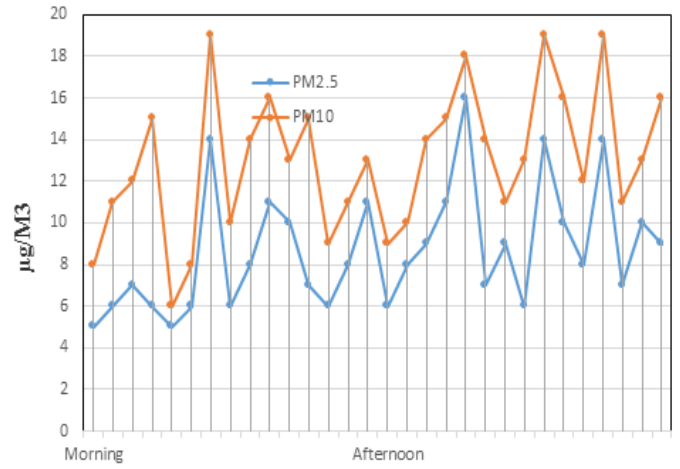

Fig 3: Average concentrations of particulate matter in August

In general, it has been found that there were high levels of particulate matter pollution probably due to local warming and season change in this region. In another study, Chaloulakou et al. (2003) measured the concentration of particulate matter $\left(\mathrm{PM}_{10}\right.$ and $\left.\mathrm{PM}_{2.5}\right)$ in the central part of Athens, Greece. Sampling site was selected close to a busy street with high traffic. Finally, the average of 24-hour $\mathrm{PM}_{10}$ concentration during the whole sampling period was $75.5 \mu \mathrm{g} / \mathrm{m}^{3}$ and the average concentration of $\mathrm{PM}_{2.5}$ was $40.2 \mu \mathrm{g} / \mathrm{m}^{3}$. Generally, it can be said that concentrations of $\mathrm{PM}_{2.5}$ and $\mathrm{PM}_{10}$ were below the standard limit in most cases. Given the fact that this study was done in spring and summer seasons, it is suggested to routinely conduct such studies other seasons of the year to better understand the concentrations of these pollutants. It is also necessary that the Environmental Protection Agency consider the establishment of more fixed stations around the city to measure air pollutants (currently there are only two pollution control stations in Shiraz) and in addition to determining the size of air pollutant particles, similar investigations should be done to assess the type of particles and sources of air pollutants in Shira

\section{REFERENCES}

Afyuni M; Erfanmanesh M (2008). Environmental EM-OPolution (water, Soil, Air). Etehad Press. Isfahan. PP: 400. (In Persian).
Arfaeinia H; Kermani M; Aghaei M; Bahrami-Asl F; Karimzadeh S (2014). Comparative Investigation of Health Quality of Air in Tehran, Isfahan and Shiraz Metropolises in 2011-2012. Journal of Health in the Field 1(4), 37-44.

Azizifar M; Nadafi K; Mohamadian M; Safdari M; Khazayi M (2011). Investigation of air quality index and concentration of suspended particle with aerodynamic diameter in air of Qom city. Qom university of medical science journal 5(2), 59-64.

Chaloulakou A; Kassomenos P; Spyrellis N; Koutrakis P (2003). Measurements of PM 10 and $P M_{2.5}$ particle concentrations in Athens, Greece, Atmospheric Environment 37(5), 649-660.

Houthuijs D; Breugelmans O; Hoek G. (2001). PM 10 and $P M_{2.5}$ concentrations in Central and Eastern Europe:: results from the Cesar study, Atmospheric Environment 35(15), 2757-2771.

Jamshidi A; Karimzadeh-Shirazi K; Raygan-Shirazi AR. (2005). Particulate Air Pollution Concentration in the City of Gachsaran, 20052006. Armaghan-E-Danesh journal 12(2): 89-97.

Hatami H; Razavi SM; Eftekhar-Ardebili H; Majlesi F (2012). The Textbook of Public Health. Arjmand Press. Shahid Beheshti university. PP: 2382.

Kermani M; Arfaeinia $\mathrm{H}$; Nabizadeh R; Alimohammadi M; Alamolhoda AA; Bahrami-asl F; Shahsavani A (2014). Study on Concentration of Particulate Matter with Diameter Less than 10 Microns, Heavy Metals and Polycyclic Aromatic Hydrocarbons Related to PM2.5 in the Ambient Air of Sina Hospital District. J. Environ. Health. Engineer. 1(2), 93-103.

Lily M; Nadafi K; Nabizadeh R; Younesian M; Mesdaghinia A; Nazm-Ara Sh (2009). Concentration of suspended particle and Air quality index in corridors of Tehran city. J. Sch. Pub. Health. Inst. Pub. Res. 7(1), 57-67. 